\title{
Preface for the Vladimir Parpura Honorary Issue of Neurochemical Research
}

\author{
Alexei Verkhratsky ${ }^{1,2,3} \cdot$ Arne Schousboe $^{4} \cdot$ Robert Zorec $^{3,5}$ \\ Published online: 18 August 2021 \\ (c) The Author(s), under exclusive licence to Springer Science+Business Media, LLC, part of Springer Nature 2021
}

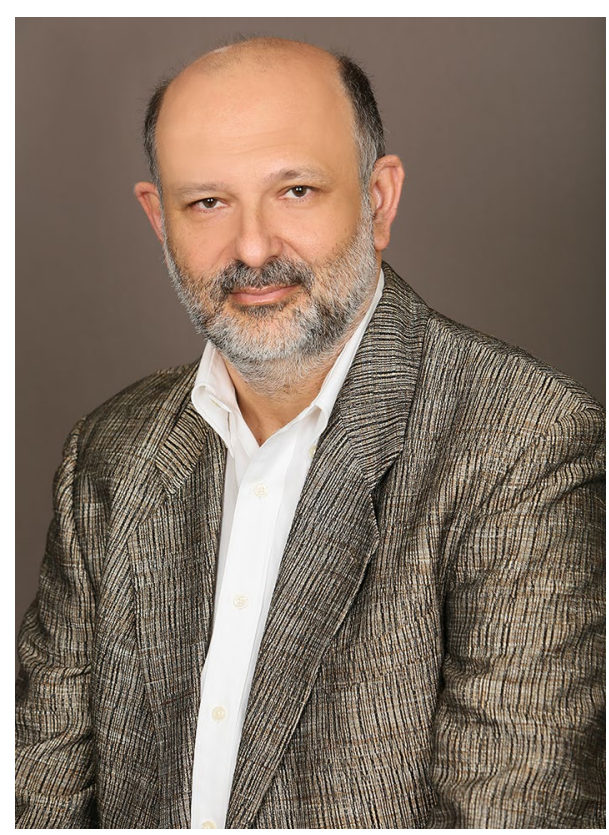

Vladimir Parpura

Special issue: In honor of Prof. Vladimir Parpura.

Alexei Verkhratsky

Alexej.Verkhratsky@manchester.ac.uk

1 Faculty of Biology, Medicine and Health, The University of Manchester, Manchester, UK

2 Achucarro Center for Neuroscience, IKERBASQUE, 48011 Bilbao, Spain

3 Celica BIOMEDICAL, Tehnološki park 24, 1000 Ljubljana, Slovenia

4 Department of Drug Design and Pharmacology, Faculty of Health and Medical Sciences, University of Copenhagen, Jagtvej 160, 2100 Copenhagen, Denmark

5 Laboratory of Neuroendocrinology-Molecular Cell Physiology, Institute of Pathophysiology, Faculty of Medicine, University of Ljubljana, Zaloška 4, 1000 Ljubljana, Slovenia
Vladimir Parpura has joined academia at the particular time and at the particular place: he started his scientific career under the supervision of Phil Haydon who led one of the very few laboratories studying neuroglia in the late 1980s-early 1990s. Vlad (as he is known to all his close friends) went to US to start his PHD studies at the Department of Zoology of the Iowa State University in 1989 after receiving the medical degree from the University of Zagreb. He begun working with astrocytes, the cells which did not receive much attention at the time; nobody however knew that the Renaissance of glial research has already begun, and Vlad was to be a prominent actor. The glial spring was in the air; the year 1988 witnessed the creation of the first dedicated journal, the Glia under the ever-lasting leadership of Helmut Kettenmann and Bruce Ransom. 
The neuroglia has been born in 1850s, after Rudolf Virchow introduced the concept of the connective tissue of the brain, into which "the nervous elements are embedded". This Nervenkitt or neuroglia has been, according to Virchow, also "the most frequent seats of morbid change" ([1-3], for historic account on neuroglia see also [4-6]). The neuroglia rapidly gained interest, with every prominent neuroanatomist and neurologists of the late 19th and early twentieth centuries adding to neuroglial research. In 1850s Heinrich Müller, Max Johann Sigismund Schultze and Karl Bergmann characterised radial glia of the retina and the cerebellum; the cells which we know now as Müller and Bergmann glia [7-9]. In 1865 Otto Deiters isolated and visualised parenchymal glial cells, which we now know as astrocytes [10]. In 1870s Camillo Golgi introduced 'reazione nera' that allowed precise visualisation of neural cells. Golgi was the first to make detailed morphological description of multiple glial morphotypes and described glial endfeet in various parts of the brain. Golgi was also the first to contemplate the role of neuroglia in nurturing the brain; he regarded endfeet as an interface between the circulation and nervous tissue serving for distributing the nutritive material from the blood to the nervous parenchyma [11-14].

The term astrocyte $(\alpha \sigma \tau \rho \circ \nu \kappa \psi \tau \sigma \sigma ;$; astron, star, kytos, a hollow vessel, later cell i.e. star-like cell) was introduced in 1895 by Michael von Lenhossek to define the stellate (as it appeared under Golgi staining) parenchymal glia [15]. This term gained universal acceptance within the next two decades being particularly popularised by Santiago Ramon y Cajal. Cajal developed the gold and mercury chloride-sublimate staining method specific for both protoplasmic and fibrous astrocytes [16], this technique labels intermediate filaments made from glial fibrillary acidic protein (GFAP), a protein used today as an astrocytic marker. Using this technique, Ramon y Cajal demonstrated origin of astrocytes from radial glia, and showed that astrocytes can divide in the adult brain, thus laying the basis for much later discoveries of the stem properties of astroglia [16-18]. Cajal considered astrocytes as versatile and multipurpose cells with many physiological functions. In particular, he regarded astrocytes as core regulators of functional hyperaemia, suggesting that contraction/relaxation of astroglial perivascular processes can increase or decrease the diameter of brain capillaries, thus regulating the blood flow [19]. Furthermore, Cajal contemplated (echoing the ideas of another glial visionary Karl Ludwig Schleich, see [20]) the perineuronal glia as a regulatory element of the inter-neuronal transmission and envisaged glial regulation as one of the principle mechanisms of sleep. In particular, Cajal suggested that astrocytes switch between active and passive states of the neuronal networks: retraction of astroglial processes allows information flow to promote wakefulness, whereas extension of astroglial processes applies a break on interneuronal connectivity, thus inducing sleep [19, 21]. Secretory function of neuroglia was proposed by Hans Held and Jean Nageotte [22, 23]. In 1907 Ernesto Lugaro published a concise and prophetic paper "Sulle funzioni della nevroglia" [24], in which he suggested that glia are involved in removal and catabolism of toxic substances, provide a special environment facilitating and guiding outgrowth of neuronal processes through secreting chemoattractants and proposed the role of glia in regulation of synaptic transmission through removal of chemical transmitters.

Discovery of neuronal ionic electrical excitability in 1940s and 1950s [25-29] has opened a new era in neuroscience: neurones can now be interrogated at a single cell level, and their electrical signals can be monitored over time in vitro, in situ and in vivo. Glial cells are non-electrically excitable; when probing with intracellular electrodes they show slow and small fluctuations in the membrane potential, which nonetheless may follow neuronal excitation [30-35]. These voltage responses generated following neuronal activity were generally considered of a passive nature reflecting redistribution of, mainly, $\mathrm{K}^{+}$ions. As the result, main focus of neuroscience shifted towards neuronal excitability and action-potential driven encoding in neuronal networks; for several decades glial cells went out of fashion. The tide begun to turn in 1980s when neurotransmitter receptors had been discovered in astrocytes and oligodendroglial cells [36, 37], while fluctuations in cytoslic $\mathrm{Ca}^{2+}$ as well as propagating $\mathrm{Ca}^{2+}$ waves had been imaged in cultured glia $[38,39]$, thus paving the way to the concept of glial ionic excitability [40-42].

This was the state of the glial art in 1989 when Vlad started his first experiments on mixed hippocampal cultures trying to reveal mechanisms of modulation of synaptic transmission. Then the serendipity, which often interferes with research, did emerge, when Srdija Jeftinija contacted Phil Haydon and Vlad with a proposal to look at $\mathrm{Ca}^{2+}$-dependent glutamate release from glial cells. On May 5, 1992, the pilot experiments on DRG glia explants and hippocampal dissociated cultures were carried out. Perfusion with bradykinin (a potent metabotropic agonist) raised intracellular $\mathrm{Ca}^{2+}$ levels in dorsal root ganglia (DRG) glia and in astrocytes. It should be noted that these DRG glia explants were not only devoid of neurones, but were also depleted of fibroblasts; they contained mainly Schwann cells and some satellite glial cells. Having exciting initial results, Parpura, Jeftinija and Haydon designed the full set of experiments to test: (i) whether bradykinin-induced release of glutamate and aspartate from DRG glia operates via $\mathrm{Ca}^{2+}$-dependent mechanism involving the endoplasmic reticulum store; and (ii) the existence of glutamate-mediated astrocyte-neurone signalling in hippocampal cultures. These two proposed studies took different paths to fruition. 
The DRG glia study went smoothly and the paper was submitted to Nature on August 11, 1993. From there on things turned out rocky as the work was flatly rejected at the editorial level. It was then submitted to Science, where it was reviewed and deemed "interesting and important", "show convincingly and for the first time", but it was rejected. After an appeal to the editorial decision, the rejection was final. The paper was than submitted to Neuron, from where it was quickly returned without peer-review and with suggestion by two members of the editorial board that the work "would be most appropriate for another journal". It was then submitted to the Journal of Neuroscience and after three revisions accepted and published in August of 1995 [43].

Meanwhile, $\mathrm{Ca}^{2+}$ imaging experiments on hippocampal astrocytes continued to work perfectly. Additionally, cortical astrocytes were also tested and showed robust BK-induced $\mathrm{Ca}^{2+}$ responses, while solitary neurones failed to respond to BK. Experiments using hippocampal neurones grown on a feeder layer of astrocytes worked the first time they were attempted on January 4, 1993, but in subsequent runs neuronal responses to BK (as per subsequent experiments due to glutamate release from astrocytes) became meek, which was certainly consistent with HPLC data on BK-induced glutamate release from hippocampal astrocytes. As fresh HPLC data showed robust BK-induced glutamate release from cortical astrocytes, results aligned with $\mathrm{Ca}^{2+}$ experiments, the decision was made to scrap out hippocampal culture data and repeat all experiments done thus far and focus solely on cultured cells obtained from cortex, more specifically from visual cortex. Such experiments started on May 28, 1993 and since then the study was fully executed with only minor problems. The paper was submitted to Nature on November 5, 1993 and after three revisions was published in July of 1994 [44].

Thus the concept of gliotransmision was born, to occupy gliologists minds since, with numerous debates and controversies [45-49]. The discovery of astrocytic $\mathrm{Ca}^{2+}$-dependent secretion also was instrumental for the emergence of the concept of tripartite synapse that elevated glia to a legitimate neuronal partner in neurotransmission [50]. This concept forced the rethinking of glial role in the physiology of the brain and has been further advanced into the concept of brain active milieu [51]. Ensuing experiments on $\mathrm{Ca}^{2+}$-dependent secretion in astrocytes revealed that this process differs to that in neurones; the kinetics of glial exocytosis is much slower $[48,52]$, this being likely a consequence of different sets of SNARE proteins mediating membrane fusion. Vlad and his colleagues discovered that instead of SNAP-25, astrocytes contain SNAP-23 [53], which defines the dynamics of exocytotic response [54]. Furthermore, Vlad contributed significantly to the understanding of the function of SNARE proteins in exocytosis by introducing atomic force spectroscopy [54] to study the interaction between proteins forming the SNARE complex. In combination with single vesicle fusion studies and atomic force spectroscopy the results revealed that molecules interacting with the SNARE complexes, including the Munc18-1 protein, tune the interactions between SNARE proteins providing a safeguarding mechanism for vesicular tethering/docking to occur via the ternary SNARE complex, and through this permitting the transition of vesicle stages between states with a narrow fusion pore to states with wider exocytotic fusion pores leading to full fusion [55].

After successful years at Iowa, Vlad joined the University of California Riverside (UCR) as an Assistant Professor in July of 2000 and climbed to the rank of Associate Professor with tenure in July 2005. Then Vlad made a lateral move to The University of Alabama at Birmingham (UAB) in July 2007 where he is working since. At UAB, Vlad was promoted to the rank of full Professor in October of 2015. The main research topic remained, however, the same: the role of astrocytes in brain function.

It is impossible to even briefly overview all discoveries made by Vlad over last 30 years: he studied secretory molecules in astrocytes and glial signalling in Caenorhabditis elegans, he researched TRP channels and mitochondrial $\mathrm{Na}^{+}-\mathrm{Ca}^{2+}$ exchanger, he analysed pathophysiology of glia in animal models of neuropsychiatric and neurodegenerative diseases, and he studied interactions between carbon nanotubes and neurones and astrocytes. All these were published in more than 180 journal write-ups, 8 books and numerous book chapters, and cited in excess of 14,000 times.

The papers included in this honorary issue reflect in many ways the significance of the work of Vlad and many of the authors have benefitted from his contributions.

Alexei Verkhratsky, Arne Schousboe,

Robert Zorec, Guest Editors

\section{References}

1. Virchow R (1856) Gesammelte Abhandlungen zyr wissenschaftlischen Medizin. Verlag von Meidinger Sohn \& Comp., Frankfurt

2. Virchow R (1858) Die Cellularpathologie in ihrer Begründung auf physiologische und pathologische Gewebelehre 20 Vorlesungen, gehalten während d. Monate Febr., März u. April 1858 im Patholog. Inst. zu Berlin, August Hirschwald, Berlin

3. Virchow RLK (1860) Cellular pathology. John Churchill, London

4. Somjen GG (1988) Nervenkitt: notes on the history of the concept of neuroglia. Glia 1:2-9. https://doi.org/10.1002/glia.440010103

5. Chvatal A, Verkhratsky A (2018) Early history of neuroglial research: personalities. Neuroglia 1:245-281. https://doi.org/10. 3390/neuroglia1010016 
6. Kettenmann H, Verkhratsky A (2008) Neuroglia: the 150 years after. Trends Neurosci 31:653-659. https://doi.org/10.1016/j.tins. 2008.09.003

7. Müller H (1851) Zur Histologie der Netzhaut. Zeitschrift für wissenschaftliche Zoologie 3:234-237

8. Schulze M (1859) Observationes de retinae structura penitiori. University of Bonn, Bonn

9. Bergmann C (1857) Notiz über einige Structurverhältnisse des Cerebellum und Rückenmarks. Zeitschrift für rationelle Medicin $8: 360-363$

10. Deiters $O$ (1865) Untersuchungen über Gehirn und Rückenmark des Menschen und der Säugethiere. Vieweg, Braunschweig

11. Golgi C (1885) Sulla fina anatomia degli organi centrali del systema nervoso.Studi di Camillo Golgi Professore di Pathologia Generale e Istologia nell'Universita di Pavia (con 24 tavole), Tip. S. Calderini e Figlio, Reggio Emila

12. Golgi C (1870) Sulla sostanza connettiva del cervello. Gazzetta Medica Italiana, Lombardia 19:145-146

13. Golgi C (1873) Suella struttura della sostanza grigia del cervello (comunicazione preventiva). Gazzetta Medica Italiana, Lombardia 33:244-246

14. Golgi C (1903) Opera omnia. Hoepli, Milano

15. Lenhossék MV (1895) Der feinere Bau des Nervensystems im Lichte neuester Forschung, 2nd edn. Fischer's Medicinische Buchhandlung $\mathrm{H}$. Kornfield, Berlin

16. y Cajal SR (1913) Un nuevo proceder para la impregnación de la neuroglía. Bol Soc Esp Biol II:104-108

17. y Cajal SR (1913) Contribucion al conocimiento de la neuroglia del cerebro humano. Trab Lab Invest Biol Univ Madrid 11:255-315

18. y Cajal SR (1916) El proceder del oro-sublimado para la coloracion de la neuroglia. Trab Lab Invest Biol Univ Madrid $14: 155-162$

19. y Cajal SR (1895) Algunas conjeturas sobre el mechanismoanatomico de la ideacion, asociacion y atención. Imprenta y Libreria de Nicolas Moya, Madrid

20. Schleich CL (1894) Schmerzlose Operationen: Örtliche Betäubung mit indiffrenten Flüssigkeiten. Psychophysik des natürlichen und künstlichen Schlafes. Springer, Berlin

21. y Cajal SR (1925) Contribution a la connaissance de la nevroglia cerebrale et cerebeleuse dans la paralyse generale progressive. Trab Lab Invest Biol Univ Madrid 23:157-216

22. Held H (1909) Über die Neuroglia marginalis der menschlichen Grosshirnrinde Monatschr. f Psychol u Neurol 26:360-416

23. Nageotte J (1910) Phenomenes de secretion dans le protoplasma des cellules nevrogliques de la substance grise. C R Soc Biol (Paris) 68:1068-1069

24. Lugaro E (1907) Sulle funzioni della nevroglia. Riv Pat Nerv Ment 12:225-233

25. Cole KS (1949) Dynamic electrical characteristics of the squid axon membrane. Arch Sci Physiol 3:253-258

26. Cole KS, Curtis HJ (1939) Electric impedance of the squid giant axon during activity. J Gen Physiol 22:649-670

27. Hodgkin AL, Huxley AF (1939) Action potentials recorded from inside a nerve fibre. Nature 144:710-711

28. Hodgkin AL, Huxley AF (1952) A quantitative description of membrane current and its application to conduction and excitation in nerve. J Physiol 117:500-544

29. Hodgkin AL, Huxley AF, Katz B (1952) Measurement of currentvoltage relations in the membrane of the giant axon of Loligo. $\mathrm{J}$ Physiol 116:424-448

30. Kuffler SW, Nicholls JG, Orkand RK (1966) Physiological properties of glial cells in the central nervous system of amphibia. J Neurophysiol 29:768-787

31. Orkand RK, Nicholls JG, Kuffler SW (1966) Effect of nerve impulses on the membrane potential of glial cells in the central nervous system of amphibia. J Neurophysiol 29:788-806. https:// doi.org/10.1152/jn.1966.29.4.788

32. Frank K, Fuortes MG (1955) Potentials recorded from the spinal cord with microelectrodes. J Physiol 130:625-654. https://doi.org/ 10.1113/jphysiol.1955.sp005432

33. Phillips CA (1956) Intracellular records from Betz cells in the cat. Quart J Exp Physiol 41:58-59

34. Somjen GG (1975) Electrophysiology of neuroglia. Annu Rev Physiol 37:163-190. https://doi.org/10.1146/annurev.ph.37. 030175.001115

35. Kelly JS, Krnjevic K, Yim GK (1967) Unresponsive cells in cerebral cortex. Brain Res 6:767-769. https://doi.org/10.1016/00068993(67)90132-1

36. Bowman CL, Kimelberg HK (1984) Excitatory amino acids directly depolarize rat brain astrocytes in primary culture. Nature 311:656-659

37. Kettenmann H, Backus KH, Schachner M (1984) Aspartate, glutamate and gamma-aminobutyric acid depolarize cultured astrocytes. Neurosci Lett 52:25-29

38. Cornell Bell AH, Finkbeiner SM, Cooper MS, Smith SJ (1990) Glutamate induces calcium waves in cultured astrocytes: longrange glial signaling. Science 247:470-473

39. Cornell-Bell AH, Finkbeiner SM (1991) $\mathrm{Ca}^{2+}$ waves in astrocytes. Cell Calcium 12:185-204. https://doi.org/10.1016/0143-4160(91) 90020-f

40. Verkhratsky A, Orkand RK, Kettenmann H (1998) Glial calcium: homeostasis and signaling function. Physiol Rev 78:99-141. https://doi.org/10.1152/physrev.1998.78.1.99

41. Verkhratsky A, Untiet V, Rose CR (2020) Ionic signalling in astroglia beyond calcium. J Physiol 598:1655-1670. https://doi.org/10. 1113/JP277478

42. Verkhratsky A, Semyanov A, Zorec R (2020) Physiology of astroglial excitability. Function 1:13-45. https://doi.org/10.1093/funct ion/zqaa016

43. Parpura V, Liu F, Jeftinija KV, Haydon PG, Jeftinija SD (1995) Neuroligand-evoked calcium-dependent release of excitatory amino acids from Schwann cells. J Neurosci 15:5831-5839

44. Parpura V, Basarsky TA, Liu F, Jeftinija K, Jeftinija S, Haydon PG (1994) Glutamate-mediated astrocyte-neuron signalling. Nature 369:744-747. https://doi.org/10.1038/369744a0

45. Nedergaard M, Verkhratsky A (2012) Artifact versus realityhow astrocytes contribute to synaptic events. Glia 60:1013-1023. https://doi.org/10.1002/glia.22288

46. Verkhratsky A, Matteoli M, Parpura V, Mothet JP, Zorec R (2016) Astrocytes as secretory cells of the central nervous system: idiosyncrasies of vesicular secretion. EMBO J 35:239-257. https:// doi.org/10.15252/embj.201592705

47. Parpura V, Zorec R (2010) Gliotransmission: exocytotic release from astrocytes. Brain Res Rev 63:83-92. https://doi.org/10. 1016/j.brainresrev.2009.11.008

48. Zorec R, Verkhratsky A, Rodriguez JJ, Parpura V (2016) Astrocytic vesicles and gliotransmitters: slowness of vesicular release and synaptobrevin2-laden vesicle nanoarchitecture. Neuroscience 323:67-75. https://doi.org/10.1016/j.neuroscience.2015.02.033

49. Araque A, Carmignoto G, Haydon PG, Oliet SH, Robitaille R, Volterra A (2014) Gliotransmitters travel in time and space. Neuron 81:728-739. https://doi.org/10.1016/j.neuron.2014.02.007

50. Araque A, Parpura V, Sanzgiri RP, Haydon PG (1999) Tripartite synapses: glia, the unacknowledged partner. Trends Neurosci 22:208-215. https://doi.org/10.1016/s0166-2236(98)01349-6

51. Semyanov A, Verkhratsky A (2021) Astrocytic processes: from tripartite synapses to the active milieu. Trends Neurosci. https:// doi.org/10.1016/j.tins.2021.07.006

52. Kreft M, Stenovec M, Rupnik M, Grilc S, Krzan M, Potokar M, Pangrsic T, Haydon PG, Zorec R (2004) Properties of 
$\mathrm{Ca}(2+)$-dependent exocytosis in cultured astrocytes. Glia 46:437445. https://doi.org/10.1002/glia.20018

53. Parpura V, Fang Y, Basarsky T, Jahn R, Haydon PG (1995) Expression of synaptobrevin II, cellubrevin and syntaxin but not SNAP-25 in cultured astrocytes. FEBS Lett 377:489-492. https:// doi.org/10.1016/0014-5793(95)01401-2

54. Montana V, Liu W, Mohideen U, Parpura V (2009) Single molecule measurements of mechanical interactions within ternary SNARE complexes and dynamics of their disassembly: SNAP25 vs. SNAP23. J Physiol 587:1943-1960. https://doi.org/10.1113/ jphysiol.2009.168575
55. Jorgacevski J, Potokar M, Grilc S, Kreft M, Liu W, Barclay JW, Buckers J, Medda R, Hell SW, Parpura V, Burgoyne RD, Zorec R (2011) Munc18-1 tuning of vesicle merger and fusion pore properties. J Neurosci 31:9055-9066. https://doi.org/10.1523/JNEUR OSCI.0185-11.2011

Publisher's Note Springer Nature remains neutral with regard to jurisdictional claims in published maps and institutional affiliations. 